See discussions, stats, and author profiles for this publication at: https://www.researchgate.net/publication/341575006

\title{
PERWUJUDAN SIMILE OLEH MERARI SIREGAR DALAM NOVEL AZAB DAN SENGSARA EMBODIMENT OF SIMILE BY MERARI SIREGAR IN NOVEL AZAB DAN SENGSARA
}

Article · May 2020

1 author:

Susiati Susiati

Universitas iqra buru

27 PUBLICATIONS 110 CITATIONS

SEE PROFILE

Some of the authors of this publication are also working on these related projects:

ANALISIS KESALAHAN BERBAHASA PADA TATARAN FONOLOGI DAN MORFOLOGI View project

linguist View project 


\title{
PERWUJUDAN SIMILE OLEH MERARI SIREGAR DALAM NOVEL AZAB DAN SENGSARA
}

\author{
EMBODIMENT OF SIMILE BY MERARI SIREGAR IN NOVEL AZAB DAN SENGSARA
}

\author{
Susiati, Risman Iye, Joleha Nacikit, Eka Wati Belen \\ Universitas Iqra Buru \\ Jalan Prof. Dr. Abd. Bassalamah, Namlea, Kabupaten Buru, Maluku \\ Telepon (0913) 21909, pos-el susiatiuniqbu@gmail.com \\ Diajukan: 27 Agustus 2019, direvisi: 21 November 2019
}

\begin{abstract}
This study aims to identify the use of simile by Merari Siregar in novel's Azab dan Sengsara. This research is a qualitative research. The data is collected using the listening method used to obtain data by listening to the use of language. The data were analyzed descriptively andthe data were analyzed based on the Kridalaksana word class manifestation theory and stylistic theory by Keraf. The type of data is written data, that is simile style language in the novel's Azab dan Sengsara by Merari Siregar. The results showed that the embodiment of simile to Merari Siregar in novel's Azab dan Sengsara have five, namely (1) embodiment of simile in the noun class with nouns; (2) embodiment of simile in the noun class with adjectives; (3) embodiment of simile in the adjectives class with verb; (4) embodiment of simile in the verb class with verb; (5) embodiment of simile in the verb class with nouns. While, simile markers to Merari Siregar in novel's Azab dan Sengsara, namely sebagai, ibarat, seperti, tak ubahnya, laksana, dan seolah-olah.
\end{abstract}

Keywords: simile, novels, Azab dan Sengsara

\begin{abstract}
Abstrak
Penelitian ini bertujuan untuk mengidentifikasi penggunaan simile oleh Merari Siregar da lam novel Azab dan Sengsara. Penelitian ini merupakan penelitian kualitatif. Data dikumpulkan menggunakan metode simak, yakni metode yang digunakan untuk memperoleh data dengan melakukan penyimakan terhadap penggunaan bahasa. Data dianalisis s ecara deskriptif da $\mathrm{n}$ data dianalisis berdasarkan teori perwujudan kelas kata Kridalaksana dan teori gaya bahasa Keraf. J en is da tanya a dalah data tertulis, yaitu majas simile dalam novel Azab dan Sengsara karya Merari Siregar. Hasil penelitian menunjukkan bahwa perwujudan simile dalam novel Azab dan Sengsara a da li ma, ya kni (1) perwujudan simile dalam kelas kata nomina dengan nomina; (2) perwujudan simile dal am kelas kata nomina dengan a djektiva; (3) perwujudan simile dalam kelas kata adjektiva dengan verba; (4) perwujudan simile dalam kelas kata verba dengan verba; (5) perwujudan simile dalam kelas kata verba dengan nomina. Sementara itu, penanda simile yang digunakan ol eh Merari Siregar dalam novel Azab dan Sengsaraadalahibarat, seperti, tak ubahnya, laksana, dan seolah-olah.
\end{abstract}

Kata kunci: simile, novel, azab dan sengsara 


\section{Pendahuluan}

Karya sastra merupakan suatu ekspresi diri pengarang yang diungkapkan melalui alat, yakni bahasa. Bahasa dalam sastra berfungsi sebagai pengungkapan ide atau gagasan yang diperoleh dari pengalaman dan penghayatan hidup pengarangnya.

Sastra merupakan karya fiksi melalui imajinasi dan pemikiran mendalam dari para pengarang, lebih dari itu merupakan bentuk kreativitas pengarang dalam menggali dan mengolah gagasan atau idenya. Sastra juga merupakan bagian dari manifestasi keadaan sosial kemasyarakatan. Karya sastra adalah suatu wujud yang mencerminkan perilaku, kejadian, keunikan, keberagaman masyarakat dalam setiap kurun waktu tertentu. Segala wujud cerminan masyarakat dapat digubah dalam sebuah sketsa karya sastra dengan tidak menghilangkan nilai rasa asli dari kenyataan yang terjadi dalam masyarakat.

Wujud karya sastra mempunyai dua aspek penting, yakni isi dan bentuk. Isinya adalah tentang pengalaman hidup manusia, sedangkan bentuknya adalah segi-segi yang menyangkut cara penilaian, yaitu cara sastrawan memanfaatkan bahasa yang indah untuk mewadahi isinya (Semi, 1989:8). Bahasa merupakan unsur penting dalam karya sastra karena perannya sebagai sarana pengungkapan dan penyampaian pesan dalam karya sastra. Penggunaan bahasa dalam karya sastra berbeda dengan penggunaan bahasa dalam karya ilmiah, misalnya ceramah dan pidato. Bahasa yang digunakan pengarang dalam suatu karya sastra merupakan gaya pembungkus idenya dalam meng- ekspresikan imajinasinya terhadap suatu objek sehingga sering disebut dengan gaya bahasa atau majas (style language).

Penggunaan gaya bahasa dalam karya sastra memiliki nilai rasa, seni, dan estetika yang tinggi yang dapat memperlihatkan ciri pribadi pengarang. Buffon (dalam Junus, 1989:20) menyatakan bahwa gaya adalah orang (penulis) itu sendiri. Dengan mengatakan gaya sebagai serangkaian ciri pribadi, pengarang dalam membuat karyanya akan memperlihatkan penggunaan bahasa yang khas dengan ciri atau karakteristik tersendiri yang berbeda dari pengarang lainnya.

Enkvist (dalam Junus, 1989:31) menyatakan bahwa gaya adalah sekumpulan ciri kolektif. Artinya, keberadaan gaya bersama dimiliki oleh dua orang pengarang atau lebih. Seperti yang diungkapkan oleh Junus (1989:34), bahwa jika dalam pengungkapan ciri pribadi yang ditonjolkan adalah perbedaan antara pengarang yang satu dan pengarang lainnya, pada persoalan gaya sebagai ciri kolektif atau gaya sosial, yang harus dicari adalah sekumpulan teks yang ditekankan pada hakikat persamaan.

Gaya bahasa atau majas dominan dipakai dalam karya-karya sastra seperti gaya bahasa perumpamaan (simile), metafora, personifikasi, litotes, alegori, hiperbola, dan masih banyak lagi. Penelitian ini dikhususkan untuk mengidentifikasi perwujudan gaya bahasa simile yang digunakan oleh Merari Siregar. Kekhasan perwujudan gaya bahasa simile oleh Merari Siregar dalam novel Azab dan Sengsara memperlihatkan ciri pribadinya dalam menulis jalan cerita dalam novel 
tersebut dan karakteristiknya menyelami karya-karyanya.

Karakteristik perwujudan simile Merari Siregar dalam novel Azab dan Sengsara sangat bervariatif. Hal ini dapat dilihat dari ranah terbanding dan ranah pembanding, misalnya wujud nomina, verba, adjektiva, dan lain-lain. Penandapenanda pembanding juga sangat beragam, misalnya kata seperti, laksana, ibarat, sebagai,dan sebagainya.

Novel Azab dan Sengsara karya Merari Siregar lahir pada era Balai Pustaka. Tema Azab dan Sengsara mempermasalahkan perkawinan dalam hubungannya dengan harkat dan martabat keluarga. Penggunaan bahasa dalam novel Azab dan Sengsara bergaya Melayu kesekolahan, Melayu rendah, atau Melayu pasar.

Secara umum novel Azab dan Sengsara memiliki ciri-ciri, yakni menguatnya kesadaran individu dan menipisnya kesadaran adat, kuat diwarnai penggambaran alam dan pengungkapan perasaan.Merari Siregar mempunyai karakteristik penceritaan dan gaya karya sastranya, yakni penggunaan bahasa yang lancar dan rapi dengan gaya khotbahnya yang langsung menunjukkan perkataan atau maksudnya kepada pembaca; meminta perhatian untuk ceritanya. Ia memberi nasihat, mengecam yang kurang baik, serta memuji-muji tindakan yang menurut aturan masyarakat baik (Susiati, 2017:67).

Penelitian ini tidak terlepas dari berbagai macam penelitian yang relevan, misalnya Munir dkk. (2013:89) yang meneliti diksi dan majas dalam kumpulan puisi Nyanyian dalam Kelam karya Sutikno W.S.: Kajian Stilistika. Hasil penelitiannya adalah diksi yang ditemukan dalam kumpulan puisi Nyanyian dalam Kelam karya Sutikno
W.S. adalah kata serapan dari bahasa Jawa, bahasa asing, dan pemanfaatan sinonim. Sementara itu, majas yang ditemukan adalah majas perbandingan, metafora, perumpamaan (simile), epos, personifikasi, metonomia, sinekdoke, dan alegori.

Rachman dkk. (2013:45) meneliti majas metafora pada kumpulan sajak Chairil Anwar Aku Ini Binatang Jalang. Hasil penelitiannya adalah ditemukan beberapa hal yang berkenaan dengan unsur batin seperti makna yang terdapat dalam tiap bait puisi dan puisi secara keseluruhan. Sementara itu, untuk bidang pengajaran, hasil penelitian ini dapat membantu pelajar menemukan penggunaan majas metafora pada kumpulan sajak Chairil Anwar, menjadi masukan bagi guru bahasa Indonesia untuk memilih karya sastra sebagai bahan ajar yang berhubungan dengan penggunaan majas metafora dalam melihat pemahaman siswa tentang makna puisi.

Penelitian ini bertujuan untuk mengidentifikasi perwujudan simile oleh Merari Siregar dalam novel Azab dan Sengsara.

\section{Landasan Teori \\ Pendekatan Stilistika}

Stilistika adalah ilmu yang mempelajari gaya bahasa yang merupakan bagian linguistik yang memusatkan pada variasi-variasi penggunaan bahasa yang kompleks pada kesusatstraan. Sama halnya dengan pernyataan Endraswara (2003:72) yang menyebutkan bahwa stilistika adalah ilmu yang mempelajari gaya bahasa suatu karya sastra. Selanjutnya, ada dua pendekatan analisis stilistika, yaitu (1) dimulai dengan analisis sistem tentang linguistik karya sastra dan dilanjutkan ke interpretasi tentang ciri-ciri sastra, 
intrepretasi diarahkan ke makna secara total; (2) mempelajari sejumlah ciri khas yang membedakan satu sistem dengan sistem lain.

Sidjiman (1993:13) menyatakan bahwa stilistika adalah style, yaitu cara yang digunakan seorang pembicara atau penulis untuk menyatakan maksudnya dengan menggunakan bahasa sebagai sarana.

Menurut Teeuw (dalam Fananie, 2000:25), stilistika adalah sarana yang dipakai pengarang untuk mencapai suatu tujuan karena stilistika merupakan cara untuk mengungkapkan pikiran, jiwa, dan kepribadian pengarang dengan khasnya. Ratna (2016:167), secara definisi,mengatakan bahwa stilistika adalah ilmu yang berkaitan dengan gaya dan gaya bahasa, tetapi pada umumnya lebih mengacu pada gaya bahasa.

\section{Gaya Bahasa}

Ahmadi (1990:170) menyatakan bahwa gaya bahasa adalah penggunaan bahasa yang istimewa dan tidak dapat dipisahkan dari cara atau teknik seorang pengarang dalam merefleksikan (memantulkan dan mencerminkan) pengalaman, nilai-nilai kualitas kesadaran pikiran, dan pandangan yang istimewa atau khusus. Ahmadi membagi gaya bahasa menjadi dua, yaitu gaya bahasa penekanan yang terdiri atas 25 jenis gaya bahasa dan gaya bahasa perbandingan yang terdiri atas empat belas jenis. Lain halnya Keraf (2010:113) yang menyebutkan bahwa gaya bahasa merupakan cara untuk mengungkapkan pikiran melalui bahasa secara khas yang memperhatikan ciri dan kepribadian penulis (pemakai bahasa).

Menurut Kridalaksana (2011:76), gaya bahasa adalah pemanfaatan atas kekayaan bahasa oleh seseorang dalam bertutur atau menulis serta pemakaian ragam tertentu. Abrams (dalam Nurgiyantoro, 2002:276) menyatakan bahwa gaya bahasa (style) adalah suatu hal yang pada umumnya tidak lagi mengandung sifat kontroversional, merujuk pada pengertian cara penggunaan bahasa dalam konteks tertentu, oleh pengarang tertentu, dan sebagainya. Menurut Jabrohim (2000:102), gaya bahasa merupakan penggunaan bahasa sebagai media komunikasi secara khusus, yaitu penggunaan bahasa secara bergaya untuk ekspresivitas pengucapan. Gaya bahasa meliputi seluruh unsur bahasa, yaitu intonasi, bunyi, kata, dan kalimat.

Keraf (2010:115) membagi jenisjenis gaya bahasa sebagai berikut.

\section{1) Gaya Bahasa Berdasarkan Pilihan Kata}

Dalam bahasa standar (bahasa baku) dapatlah dibedakan: gaya bahasa resmi (bukan bahasa resmi), gaya bahasa tak resmi, dan gaya bahasa percakapan (Keraf, 2010:120).

\section{2) Gaya Bahasa Bedasarkan Nada}

Gaya bahasa dilihat dari segi nada yang terkandung dalam sebuah wacana, dibagi atas: gaya yang sederhana, gaya mulia dan bertenaga, serta gaya menengah.

\section{3) Gaya Bahasa Berdasarkan Struktur Kalimat}

Gaya bahasa berdasarkan struktur kalimat terdiri atas gaya bahasa klimaks, antiklimaks,paralelisme, antitesis, dan repetisi.

\section{4) Gaya Bahasa Berdasarkan Langsung Tidaknya Makna}

Berdasarkan langsung tidaknya makna yang terkandung dalam sebuah kata atau kelompok kata, gaya bahasa dapat dibedakan atas dua bagian, yakni gaya 
langsung atau gaya bahasa retoris/gaya bahasa kiasan.

\section{a. Gaya Bahasa Retoris}

Gaya bahasa retoris harus diartikan menurut nilai lahirnya. Tidak ada usaha menyembunyikan sesuatu di dalamnya (Keraf, 2010:129). Gaya bahasa retoris terdiri atas aliterasi, asonansi, anastrof, apofasis atau preterisio, apostrof, asindeton, polisondeton, kiasmus, elipsis, eufemisme, litotes, histeron, proteron, pleonasme dan tautologi, perifrasis, prolepsis atau antisipasi, erotesis atau pertanyaan retoris, silepsis dan zeugma, koreksio atau epanortosis, hiperbola, paradoks, dan oksimoron.

\section{b. Gaya Bahasa Kiasan}

Gaya bahasa kiasan ialah gaya yang apabila dilihat dari segi makna tidak dapat ditafsirkan sesuai dengan katakata yang membentuknya. Makna harus dicari di luar rangkaian kata atau kalimatnya. Gaya bahasa kiasan terdiri atas persamaan atau simile, metafora, alegori, parabel, fabel, personifikasi, alusio, eponim, epitet, sinekdoke, metonomia, antonomasia, hipalase, ironi, sinisme, sarkasme, satire, inuendo, antifrasis, paronomasia.

\section{Simile}

Keraf (2010:138) menyatakan bahwa simile atau perumpamaan adalah perbandingan yang bersifat eksplisit, yaitu gaya bahasa langsung yang menyatakan sesuatu sama dengan hal yang lain. Simile atau perumpamaan memerlukan upaya yang secara eksplisit menunjukkan kesamaan itu, yaitu katakata: seperti, sama, sebagai, bagaikan, bagai, laksana, seolah-olah, tak ubahnya, dan sebagainya.

Menurut Tarigan (1986:144), simile atau perumpamaan adalah per- bandingan dua hal yang pada hakikatnya berlainan dan dianggap sama. Perbandingan ini secara eksplisit dijelaskan dengan pemakaian kata seperti, sebagai, bagaikan, laksana, umpama, ibarat, dan sejenisnya. Contohnya adalah kikirnya seperti kepiting batu.

Terdapat dua kata (atau bentuk lainnya) dalam simile atau perumpamaan yang masing-masing menampilkan konsep dan acuan yang berbeda. Menurut pandangan tiap budaya, perumpamaan dalam sebuah bahasa dapat berbeda-beda bergantung dari latar belakang masyarakat tentang pengetahuan yang mereka pahami. Jadi, dalam simile dapat berupa perumpamaan secara orisinal atau perumpamaan secara kesepakatan kelompok masyarakat yang makna antara pembanding dan terbanding memiliki kesamaan komponen makna. Dengan begitu, kedua benda atau hal yang diperumpamakan bisa diperbandingkan. Perbandingan ini tidak menimbulkan masalah. Majas ini mudah dikenali karena kedua penanda muncul secara bersamaan dan selalu dihubungkan oleh kata pembandingnya.

Contoh:

Tutur manisnya seperti madu.

Bagan wilayah makna yang diperumpamakan pada contoh tersebut adalah frasa tutur manisnya dengan kata madu. Komponen makna penyama pada frasa tutur manisnya dan kata madu adalah merasa enak dan terpengaruh. Komponen makna pembeda pada frasa tutur manisnya bermakna cara bertutur yang enak didengar atau mengandung rayuan sehingga yang mendengarnya dapat terpengaruh. Sementara itu, kata madu merupakan cairan yang banyak mengandung zat gula yang rasanya manis sekali. Jadi, komponen makna 
penyama dan pembeda pada dua hal yang dipersamakan untuk frasa tuturmanisnya terletak pada cara dan pada kata madu terletak pada sifatnya.

Simile merujuk pada adanya perbandingan yang langsung dan eksplisit dengan mempergunakan katakata tugas tertentu sebagai penanda keeksplisitan seperti: seperti, bagai, bagaikan, sebagai, laksana, mirip, dan sebagainya (Nurgiyantoro, 2014:298).

\section{Perwujudan Kelas Kata}

Menurut Kridalaksana (2011:110), kata adalah morfem atau kombinasi morfem yang oleh bahasawan dianggap sebagai satuan terkecil yang dapat diujarkan sebagai bentuk yang bebas atau satuan bahasa yang dapat berdiri sendiri, terdiri atas morfem tunggal atau morfem gabungan. Kata tunggal atau morfem tunggal adalah kata yang berasal dari leksem tunggal setelah mengalami proses morfologi. Kata kompleks adalah kata yang sudah mengalami proses morfologis. Kata golongan ini dapat dibedakan menjadi tiga, yaitu (1) kata berimbuhan; (2) kata ulang; (3) kata majemuk. Kata berimbuhan adalah kata yang dibentuk dengan proses afiksasi, sedangkan kata ulang adalah kata yang dibentuk dengan proses reduplikasi. Kridalaksana (2009:28) mengatakan bahwa kata majemuk adalah gabungan morfem dasar yang seluruhnya berstatus sebagai kata yang mempunyai pola fonologis, gramatikal, dan semantik yang khusus menurut kaidah yang bersangkutan. Kridalaksana (2009:29) menggolongkan kelas kata menjadi tiga belas kata, yaitu verba (kata kerja), adjektiva (kata sifat), nomina (kata benda), pronomina (kata ganti), numeralia (kata bilangan), adverbia (kata keterangan), interogativa (kata tanya), demonstrativa (kata tunjuk), preposisi (kata depan), konjungsi (kata penghubung), artikula, kategori fatis, dan interjeksi (kata seru).

\section{Metode Penelitian}

\subsection{Jenis penelitian dan Pendekatan}

Penelitian ini merupakan jenis penelitian deskriptif kualitatif dengan menggunakan pendekatan stilistika. Jenis penelitian deskriptif kualitatif adalah salah satu prosedur penelitian yang menghasilkan data deskriptif berupa ucapan atau tulisan dan perilaku orang-orang yang diamati (Bodgan dan Taylor dalam Moleong, 2007:67).

Sementara, pendekatan stilistika memberikan perhatian terhadap tampilan bahasa di dalam karya sastra.

\section{Metode Penelitian}

Metode yang digunakan dalam penelitian ini adalah metode simak. Menurut Mahsun (2013:242), metode simak adalah metode yang digunakan untuk memperoleh data dengan melakukan penyimakan terhadap penggunaan bahasa. Teks dalam novel Azab dan Sengsara karya Merari Siregar disimak dan diamati untuk mencari penggunaan perwujudan majas simile yang terdapat dalam novel Azab dan Sengsara karya Merari Siregar, kemudian ditandai, serta didokumentasikan untuk diinventarisasikan sebagai data dalam penelitian ini. Adapun teknik yang digunakan untuk melengkapi metode simak tersebut adalah teknik catat.

Teknik catat adalah teknik yang digunakan untuk mencatat data yang ditemukan. Teknik catat merupakan teknik yang digunakan untuk mencatat beberapa bentuk yang relevan bagi penelitian yang bersumber dari penggunaan bahasa secara tertulis (Mahsun, 2013:127). Teks novel Azab 
dan Sengsara karya Merari Siregar dibaca, kemudian menandai kata-kata dalam teks novel yang mengandung majas simile.Semua data yang telah ditandai dalam novel Azab dan Sengsara karya Merari Siregar, selanjutnya disalin dalam kartu data untuk dianalisis perwujudannya.

\subsection{Sumber dan Jenis Data}

Sumber data penelitian ini adalah novel novel Azab dan Sengsara karya Merari Siregar terbitan PT Balai Pustaka, cetakan keduabelas, Jakarta (1993).

Jenis data dalam penelitian ini adalah data tertulis, yaitu majas simile dalam novel novel Azab dan Sengsara karya Merari Siregar.

\subsection{Teknis Analisis Data}

Analisis data dalam penelitian ini adalah sebagai berikut.

1. Pengidentifikasian data, yakni mengidentifikasi perwujudan simile melalui teks dalam novel Azab dan Sengsara karya Merari Siregar.

2. Pengklasifikasian data, yakni mengklasifikasi teks yang menunjukkan perwujudan similedalam novel Azab dan Sengsara karya Merari Siregar.

3. Penganalisisan data, yakni semua data yang telah diklasifikasi dianalisis dengan mendeskripsikan secara mendetail permasalahan yang ada dalam penelitian ini berupa perwujudan simile oleh Merari Siregar dalam novel Azab dan Sengsara.

\section{Pembahasan}

Pembahasan dalam penelitian ini akan mengidentifikasiperwujudan simile oleh Merari Siregar dalam novel Azab dan Sengsara yang menjadi fokus masalah.

\section{Perwujudan Simile dalam Novel Azab dan Sengsara}

Perwujudan simile dalam novel Azab dan Sengsarasangat bervariasi, yakni berwujud nomina, verba, dan adjektiva. Dalam mengidentifikasi perwujudan simile dalam novel Azab dan Sengsara, penulis menggunakan teori perwujudan kelas kata Kridalaksana dan teori gaya bahasa Keraf. Adapun perwujudan simile dalam novel Azab dan Sengsara adalah (1) perwujudan simile dalam kelas kata nomina dengan nomina; (2) perwujudan simile dalam kelas kata nomina dengan adjektiva; (3) perwujudan simile dalam kelas kata adjektiva dengan verba; (4) perwujudan simile dalam kelas kata verba dengan verba; (5) perwujudan simile dalam kelas kata verba dengan nomina. Sementara itu, penanda simile yang digunakan oleh Merari Siregar dalam novel Azab dan Sengsara adalahsebagai, ibarat, seperti, tak ubahnya, laksana, dan seolah-olah. Berikut penjelasannya.

\section{a) Perwujudan Simile dalam Kelas Kata Nomina dengan Nomina}

Perwujudan simile Merari Siregar meliputi terbanding dan pembanding. Adapun terbanding berwujud nomina konkret dan nomina abstrak, begitu pula dengan pembanding berwujud nomina konkret dan nomina abstrak. Gaya bahasa simile Merari Siregar dengan perwujudan nomina dengan nomina dalam novel Azab dan Sengsaradapat dilihat pada tabel 1 . 
Tabel 1

Perwujudan Simile oleh Merari Siregar dalam Kelas Kata Nomina dengan Nomina

\begin{tabular}{|c|c|c|c|c|c|c|}
\hline \multirow[t]{2}{*}{ No } & \multirow{2}{*}{$\begin{array}{l}\text { Kutipan Teks Novel } \\
\text { Azab dan Sengsara }\end{array}$} & \multicolumn{2}{|c|}{ Perwujudan Nomina } & \multirow{2}{*}{$\begin{array}{c}\text { Penanda } \\
\text { terbanding dan } \\
\text { Pembanding }\end{array}$} & \multirow{2}{*}{$\begin{array}{l}\text { Terbanding } \\
\text { (Teb) }\end{array}$} & \multirow{2}{*}{$\begin{array}{l}\text { Pembanding } \\
\quad(\text { Pem })\end{array}$} \\
\hline & & Teb & Pem & & & \\
\hline 1 & $\begin{array}{l}\text { Langit di sebelah } \\
\text { barat pun merah } \\
\text { kuning rupanya dan } \\
\text { sinar matahari yang } \\
\text { turun itu nampaklah } \\
\text { di atas kayu yang } \\
\text { tinggi-tinggi, indah } \\
\text { rupanya sebagai } \\
\text { disepuh dengan emas } \\
\text { juwita. (hlm.11) }\end{array}$ & $\begin{array}{l}\text { Nomina } \\
\text { konkret }\end{array}$ & $\begin{array}{l}\text { Nomina } \\
\text { konkret }\end{array}$ & Sebagai & $\begin{array}{l}\text { Langit di sebelah } \\
\text { barat pun merah } \\
\text { kuning }\end{array}$ & Emas juwita \\
\hline 2 & $\begin{array}{l}\text { Batang padi yang } \\
\text { tumbuh di sawah } \\
\text { yang luas itupun } \\
\text { dibuai-buaikan angin } \\
\text { sebagai ombak yang } \\
\text { berpalu-paluandi } \\
\text { atas laut yang lebar. } \\
\text { (hlm.11) }\end{array}$ & $\begin{array}{l}\text { Nomina } \\
\text { konkret }\end{array}$ & $\begin{array}{l}\text { Nomina } \\
\text { konkret }\end{array}$ & Sebagai & $\begin{array}{l}\text { Batang padi yang } \\
\text { tumbuh di sawah } \\
\text { yang luas itupun } \\
\text { dibuai-buaikan } \\
\text { angin }\end{array}$ & $\begin{array}{l}\text { Ombakyang } \\
\text { berpalu-paluan } \\
\text { di atas laut yang } \\
\text { lebar }\end{array}$ \\
\hline 3 & $\begin{array}{l}\text { Sawah yang luas } \\
\text { itupun tak ubahnya } \\
\text { dengan lautan. } \\
\text { (hlm.11) }\end{array}$ & $\begin{array}{l}\text { Nomina } \\
\text { konkret }\end{array}$ & $\begin{array}{l}\text { Nomina } \\
\text { konkret }\end{array}$ & Tak ubahnya & Sawah yang luas & Lautan \\
\hline 4 & $\begin{array}{l}\text { Nasib manusia itu } \\
\text { sebagai roda, kadang- } \\
\text { kadang ke atas, } \\
\text { kadang-kadang ke } \\
\text { bawah (hlm.16) }\end{array}$ & $\begin{array}{l}\text { Nomina } \\
\text { abstrak }\end{array}$ & $\begin{array}{l}\text { Nomina } \\
\text { konkret }\end{array}$ & Sebagai & Nasib manusia & Roda \\
\hline 5 & $\begin{array}{l}\text { Ah, sungguh saya } \\
\text { merasa beruntung } \\
\text { karena anak kita ini } \\
\text { sebagai matahari } \\
\text { yang menyinari } \\
\text { peernikahan kita. } \\
\text { (hlm. 26) }\end{array}$ & $\begin{array}{c}\text { Nomina } \\
\text { konkret } \\
\text { bernyawa }\end{array}$ & $\begin{array}{l}\text { Nomina } \\
\text { konkret }\end{array}$ & Sebagai & Anak & Matahari \\
\hline 6 & $\begin{array}{l}\text { Hatinya hancur } \\
\text { sebagai kaca } \\
\text { terempas ke batu... } \\
\text { (hlm.32) }\end{array}$ & $\begin{array}{l}\text { Nomina } \\
\text { abstrak }\end{array}$ & $\begin{array}{l}\text { Nomina } \\
\text { konkret }\end{array}$ & Sebagai & Hati yang hancur & $\begin{array}{l}\text { Kaca terempas } \\
\text { ke batu }\end{array}$ \\
\hline 7 & $\begin{array}{l}\text { Sipipisan pun sudah } \\
\text { hilang puncaknya } \\
\text { yang bagus itu, } \\
\text { bentuknya sebagai } \\
\text { bentuk ranggah ayam } \\
\text { jantan yang berdiri } \\
\text { dengan gagahnya. } \\
\text { (hlm. 38) }\end{array}$ & $\begin{array}{l}\text { Nomina } \\
\text { konkret }\end{array}$ & $\begin{array}{l}\text { Nomina } \\
\text { konkret }\end{array}$ & Sebagai & $\begin{array}{l}\text { Sipipisan pun } \\
\text { sudah hilang } \\
\text { puncaknya }\end{array}$ & $\begin{array}{l}\text { bentuk ranggah } \\
\text { ayam jantan } \\
\text { yang berdiri } \\
\text { dengan gagahnya }\end{array}$ \\
\hline
\end{tabular}

Contoh (1)

Langit di sebelah barat pun merah kuning rupanya dan sinar matahari yang turun itu nampaklah di atas kayu yang tinggi-tinggi, indah rupanya sebagai disepuh dengan emas juwita. (hlm.11)

Bagan wilayah terbanding dan pembanding yang diperumpamakan pada contoh (1), yang termasuk 
terbanding adalah kalimat langit di sebelah barat pun merah kuning rupanya dengan pembanding frasa emas juwita. Komponen makna penyama pada kalimat langit di sebelah barat pun merah kuning rupanya dan frasa emas juwita adalah kesamaan warna, yakni sama-sama menghasilkan warna kekuningan. Sementara itu, komponen makna pembeda, pada kalimat langit di sebelah barat pun merah kuning rupanya bermakna warna langit ketika matahari terbenam. Frasa emas juwita bermakna emas yang berwarna kuning kemerahmerahan. Jadi, warna kekuningan yang dihasilkan oleh matahari yang terbenam diasosiasikan dengan warna emas juwita karena memiliki komponen makna penyama. Penanda simile antara pembanding dan terbanding pada contoh di atas adalah kata sebagai.

Contoh (2)

Batang padi yang tumbuh di sawah yang luas itupun dibuai-buaikan angin sebagai ombak yang berpalupaluandi atas laut yang lebar. (hlm.11)

Penanda simile antara terbanding dan pembanding pada contoh di atas adalah kata sebagai. Bagan wilayah terbanding dan pembanding yang diperumpamakan pada contoh di atas, yaitu kalimat Batang padi yang tumbuh di sawah yang luas itupun dibuai-buaikan angin merupakan terbanding dan kalimat ombak yang berpalu-paluandi atas laut yang lebar merupakan pembanding. Komponen makna penyama pada kalimat Batang padi yang tumbuh di sawah yang luas itupun dibuai-buaikan angin dan kalimat ombak yang berpalupaluan di atas laut yang lebar adalah diayun-ayunkan dan berpukul-pukulan. Sementara itu, komponen makna pembeda, pada kalimat Batang padi yang tumbuh di sawah yang luas itupun dibuai-buaikan angin bermakna batang padi yang bergerak-gerak karena tertiup oleh angin. Kalimat ombak yang berpalu-paluan di atas laut yang lebar bermakna ombak yang bergelombang. Jadi, batang padi yang dibuai-buaikan angin diasosiasikan dengan bentuk ombak yang berpalu-paluan karena memiliki komponen makna penyama.

Contoh (3)

Sawah yang luas itupun tak ubahnya dengan lautan. (hlm.11)

Bagan wilayah terbanding dan pembanding yang diperumpamakan pada contoh (3) antara lain, yang termasuk terbanding, adalahkalimat Sawah yang luasdan pembanding adalah kata lautan. Komponen makna penyama pada kalimat Sawah yang luasdan katalautan adalah lapang; lebar suatu bidang atau ruang.Jadi, sawah yang luas diasosiasikan dengan bentuk lautan yang luas.Sementara itu, komponen makna pembeda, pada kalimat sawah yang luas bermakna sawah yang ukurannya sangat lebar bidangnya. Kata lautan bermakna samudra. Penanda simile antara pembanding dan terbanding pada contoh di atas adalah kata tak ubahnya.

\section{b) Perwujudan Simile dalam Kelas Kata Nomina dengan Adjektiva}

Perwujudan simile meliputi terbanding dan pembanding.Adapun terbanding berwujud nomina konkret, nomina abstrak, dan adjektiva. Begitupula dengan pembanding berwujud nomina konkret, nomina abstrak, dan adjektiva. Perwujudan gaya bahasa simile dalam kelas kata nomina dengan adjektiva pada novel Azab dan Sengsara adalahsebagai berikut. 
Tabel 2

Perwujudan Simile oleh Merari Siregar dalam Kelas Kata Nomina dengan Adjektiva

\begin{tabular}{|c|c|c|c|c|c|c|}
\hline \multirow[t]{2}{*}{ No } & \multirow{2}{*}{$\begin{array}{c}\text { Kutipan Teks } \\
\text { Novel Azab dan } \\
\text { Sengsara }\end{array}$} & \multicolumn{2}{|c|}{ Perwujudan Nomina } & \multirow{2}{*}{$\begin{array}{c}\text { Penanda } \\
\text { terbanding } \\
\text { dan } \\
\text { pembanding }\end{array}$} & \multirow{2}{*}{$\begin{array}{l}\text { Terbanding } \\
\text { (Teb) }\end{array}$} & \multirow{2}{*}{$\begin{array}{l}\text { Pembanding } \\
\text { (Pem) }\end{array}$} \\
\hline & & Teb & Pem & & & \\
\hline 1 & $\begin{array}{l}\text { Pengetahuannya } \\
\text { tiada suatu apa } \\
\text { ibarat gendeng } \\
\text { kalau dipalu keras } \\
\text { suaranya, dibelah } \\
\text { tak ada isinya } \\
\text { (hlm.31) }\end{array}$ & $\begin{array}{l}\text { Nomina } \\
\text { abstrak }\end{array}$ & Adjektiva & Ibarat & $\begin{array}{l}\text { Pengetahuan nya } \\
\text { tiada suatu apa }\end{array}$ & Gendeng \\
\hline 2 & $\begin{array}{l}\text { Lihatlah warna } \\
\text { kulitnya yang } \\
\text { jernih dan bersih } \\
\text { itu, putih kuning } \\
\text { sebagai kulit } \\
\text { langsat. (hlm.33) }\end{array}$ & Adjektiva & $\begin{array}{l}\text { Nomina } \\
\text { konkret }\end{array}$ & Sebagai & $\begin{array}{l}\text { Warna kulitnya } \\
\text { yang jernih dan } \\
\text { bersih itu, putih } \\
\text { kuning }\end{array}$ & Kulit langsat \\
\hline 3 & $\begin{array}{l}\text { Giginya yang putih } \\
\text { dan halus, } \\
\text { berkilat-kilat } \\
\text { sebagai mutiara. } \\
\text { (hlm.33) }\end{array}$ & Adjektiva & $\begin{array}{l}\text { Nomina } \\
\text { konkret }\end{array}$ & Sebagai & $\begin{array}{l}\text { Giginya yang } \\
\text { putih dan halus }\end{array}$ & Mutiara \\
\hline 4 & $\begin{array}{l}\text { Air matanya yang } \\
\text { hening dan jernih, } \\
\text { suci dan basah } \\
\text { sebagai seri } \\
\text { gunung waktu } \\
\text { matahari akan } \\
\text { terbenam adanya } \\
\text { (hlm.33) }\end{array}$ & Adjektiva & $\begin{array}{l}\text { Nomina } \\
\text { konkret }\end{array}$ & Sebagai & $\begin{array}{l}\text { Air matanya } \\
\text { yang hening dan } \\
\text { jernih, suci dan } \\
\text { basah }\end{array}$ & $\begin{array}{l}\text { Seri gunung } \\
\text { waktu } \\
\text { matahari akan } \\
\text { terbenam }\end{array}$ \\
\hline 5 & $\begin{array}{l}\text { Hari yang kelam } \\
\text { itu menjadi kelam } \\
\text { sebagai waktu } \\
\text { matahari } \\
\text { terbenam. (hlm. } \\
\text { 38) }\end{array}$ & Adjektiva & $\begin{array}{l}\text { Nomina } \\
\text { konkret }\end{array}$ & Sebagai & $\begin{array}{l}\text { Hari yang kelam } \\
\text { itu menjadi } \\
\text { kelam }\end{array}$ & $\begin{array}{l}\text { Waktu } \\
\text { matahari } \\
\text { terbenam }\end{array}$ \\
\hline 6 & $\begin{array}{l}\text { Terasa benar- } \\
\text { benar dalam } \\
\text { hatiku: makin } \\
\text { lama makin besar } \\
\text { cinta itu sebagai } \\
\text { tanam-tanaman. } \\
\text { (hlm.71) }\end{array}$ & Adjektiva & $\begin{array}{l}\text { Nomina } \\
\text { konkret }\end{array}$ & Sebagai & Besar cinta & $\begin{array}{l}\text { Tanam- } \\
\text { tanaman }\end{array}$ \\
\hline 7 & $\begin{array}{l}\text { Akan tetapi cita- } \\
\text { cita itu sudah } \\
\text { lenyap sebagai } \\
\text { kabut ditiup angin. } \\
\text { (hlm. 71) }\end{array}$ & Adjektiva & $\begin{array}{l}\text { Nomina } \\
\text { konkret }\end{array}$ & Sebagai & $\begin{array}{l}\text { Cita-cita itu } \\
\text { sudah lenyap }\end{array}$ & $\begin{array}{l}\text { Kabut ditiup } \\
\text { angin }\end{array}$ \\
\hline
\end{tabular}

Contoh (4)

Pengetahuannya tiada suatu apa ibarat gendeng kalau dipalu keras suaranya, dibelah tak ada isinya

(hlm.31) 
Bagan wilayah terbanding dan pembanding yang diperumpamakan pada contoh (4) meliputi kalimat pengetahuannya tiada suatu apayang merupakan terbanding dan kata gendeng merupakan pembanding. Komponen makna penyama pada kalimat pengetahuannya tiada suatu apadan kata gendeng adalah bodoh; tidak punya pengetahuan. Sementara, komponen makna pembeda, pada kalimat pengetahuannya tiada suatu apa bermakna tidak pintar; kurang pintar. Sementara itu, kata gendeng bermakna gila; tidak normal. Jadi, pengetahuannya tiada suatu apa diasosiasikan dengan gendeng karena mempunyai komponen makna penyama.Penanda simile antara pembanding dan terbanding pada contoh di atas adalah kata ibarat.

Contoh (5)

Lihatlah warna kulitnya yang jernih dan bersih itu, putih kuning sebagai kulit langsat. (hlm.33)

Bagan wilayah terbanding dan pembanding yang diperumpamakan pada contoh (5) adalah kalimat warna kulitnya yang jernih dan bersih itu, putih kuning merupakan terbanding dan frasa kulit langsat merupakan pembanding. Komponen makna penyama pada kalimat warna kulitnya yang jernih dan bersih itu, putih kuning dan frasa kulit langsat adalah putih bersih. Sementara itu, komponen makna pembeda pada kalimat warna kulitnya yang jernih dan bersih itu, putih kuning bermakna mempunyai kulit yang putih kekuningkuningan. Frasa kulit langsat bermakna kulit buah yang berwarna putih atau kuning; buahnya menyerupai duku.Jadi, warna kulitnya yang jernih dan bersih itu, putih kuning disamakan dengan kulit langsat karena mempunyai komponen makna penyama. Penanda simile antara terbanding dan pembanding pada contoh di atas adalah kata sebagai.

Contoh (6)

Giginya yang putih dan halus, berkilat-kilat sebagai mutiara. (hlm.33)

Bagan wilayah terbanding dan pembanding yang diperumpamakan pada contoh (6) adalah kalimat giginya yang putih dan halus, berkilat-kilat merupakan terbanding dan kata mutiara merupakan pembanding. Komponen makna penyama pada kalimat giginya yang putih dan halus, berkilat-kilatdan kata mutiara adalah putih bersih; mengilat.Sementara itu, komponen makna pembeda, pada kalimat giginya yang putih dan halus, berkilat-kilat bermakna mempunyai bentuk giginya yang putih, bersih, dan berkilat. Kata mutiara bermakna permata berbentuk bulat dan keras yang berwarna putih.Jadi, giginya yang putih dan halus, berkilat-kilat diasosiasikan dengan mutiara karena mempunyai komponen makna penyama. Penanda simile antara pembanding dan terbanding pada contoh di atas adalah kata sebagai.

\section{c) Perwujudan Simile dalam Kelas Kata Adjektiva dengan Verba}

Perwujudan simile meliputi terbanding dan pembanding. Adapun terbanding berwujud adjektiva dan verba.Begitupula dengan pembanding berwujud adjektiva dan verba. Perwujudan simile dalam kelas kata adjektiva dengan verba pada novel $A z a b$ dan Sengsara adalahsebagai berikut. 
Tabel 3

Perwujudan Simile oleh Merari Siregar dalam Kelas Kata Adjektiva dengan Verba

\begin{tabular}{|c|c|c|c|c|c|c|}
\hline \multirow[t]{2}{*}{ No. } & \multirow{2}{*}{$\begin{array}{c}\text { Kutipan Teks } \\
\text { Novel Azab dan } \\
\text { Sengsara }\end{array}$} & \multicolumn{2}{|c|}{ Perwujudan Nomina } & \multirow{2}{*}{$\begin{array}{c}\text { Penanda } \\
\text { terbanding } \\
\text { dan } \\
\text { pembanding }\end{array}$} & \multirow{2}{*}{$\begin{array}{l}\text { Terbanding } \\
\text { (Teb) }\end{array}$} & \multirow{2}{*}{$\begin{array}{l}\text { Pembanding } \\
\text { (Pem) }\end{array}$} \\
\hline & & Ter & Pem & & & \\
\hline 1 & $\begin{array}{l}\text { Pencarian } \\
\text { istrinya itu pun, } \\
\text { karena ia masih } \\
\text { juga bekerja di } \\
\text { rumah tuannya, } \\
\text { tiada tinggal, } \\
\text { tandas sama } \\
\text { sekali sebagai } \\
\text { hujan jatuh ke } \\
\text { pasir (hlm.31) }\end{array}$ & Adjektiva & Verba & Sebagai & $\begin{array}{l}\text { Pencarian } \\
\text { tiada tinggal, } \\
\text { tandas sama } \\
\text { sekali }\end{array}$ & $\begin{array}{l}\text { Hujan jatuh ke } \\
\text { pasir }\end{array}$ \\
\hline 2 & $\begin{array}{l}\text { Lenyap dari mata } \\
\text { sedang suaranya } \\
\text { minta tolong itu } \\
\text { sia-sia saja } \\
\text { sebagai jatuh ke } \\
\text { lubuk. (hlm.136) }\end{array}$ & Adjektiva & Verba & Sebagai & $\begin{array}{l}\text { Suaranya } \\
\text { minta tolong } \\
\text { itu sia-sia saja }\end{array}$ & Jatuh ke lubuk \\
\hline
\end{tabular}

\section{Contoh (7)}

Pencarian istrinya itu pun, karena ia masih juga bekerja di rumah tuannya, tiada tinggal, tandas sama sekali sebagai hujan jatuh ke pasir (hlm.31)

Bagan wilayah terbanding dan pembanding yang diperumpamakan pada contoh (7) adalah kalimat pencarian tiada tinggal, tandas sama sekalimerupakanterbanding dan kalimathujan jatuh ke pasirmerupakan pembanding. Komponen makna penyama pada kalimat pencarian tiada tinggal, tandas sama sekalidan kalimat hujan jatuh ke pasiradalah pendapatan yang tidak menyisakan sesuatu. Sementara itu, komponen makna pembeda, pada kalimat pencarian tiada tinggal, tandas sama sekalibermakna uang yang didapat langsung habis saat itu juga. Kalimat hujan jatuh ke pasir bermakna cairan hujan yang jatuh ke pasir langsung terserap ke dalam, tidak menyisakan cairannya di atas permukaan. Jadi, pencarian tiada tinggal, tandas sama sekali diasosiasikan dengan hujan jatuh ke pasir karena mempunyai komponen makna penyama. Penanda simile antara pembanding dan terbanding pada contoh di atas adalah kata sebagai.

Contoh (8)

lenyap dari mata sedang suaranya minta tolong itu sia-sia saja sebagai jatuh ke lubuk. (hlm.136) 
Bagan wilayah terbanding dan pembanding yang diperumpamakan pada contoh (8), yang termasuk terbanding, adalah kalimat suaranya minta tolong itu sia-sia sajadan pembanding adalah kalimat jatuh ke lubuk. Komponen makna penyama pada kedua contoh kalimat tersebut adalah sesuatu yang tak terdengar atau lenyap. Sementara itu, komponen makna pembeda, pada kalimat suaranya minta tolong itu sia-sia sajabermakna suatu teriakan yang semakin hilang tidak terdengar. Kalimat jatuh ke lubukbermakna sesuatu yang jatuh ke dasar yang terdalam tak terlihat; hilang lenyap. Jadi, suaranya minta tolong itu sia-sia saja diasosiasikan dengan jatuh ke lubuk karena mempunyai komponen makna penyama. Penanda simile antara pembanding dan terbanding pada contoh di atas adalah kata sebagai.

\section{d) Perwujudan Simile dalam Kelas Kata Verba dengan Verba}

Perwujudan simile meliputi terbanding dan pembanding.Adapun terbanding dan pembanding berwujud verba dan verba. Perwujudan simile dalam kelas kata verba dengan verba pada novel Azab dan Sengsara adalahsebagai berikut.

Tabel 4

Perwujudan Simile oleh Merari Siregar dalam Kelas Kata Verba dengan Verba

\begin{tabular}{|c|c|c|c|c|c|c|}
\hline \multirow[t]{2}{*}{ No. } & \multirow{2}{*}{$\begin{array}{c}\text { Kutipan Teks } \\
\text { Novel Azab dan } \\
\text { Sengsara }\end{array}$} & \multicolumn{2}{|c|}{$\begin{array}{c}\text { Perwujudan } \\
\text { Nomina }\end{array}$} & \multirow{2}{*}{$\begin{array}{c}\text { Penanda } \\
\text { terbanding } \\
\text { dan } \\
\text { pembanding }\end{array}$} & \multirow[t]{2}{*}{$\begin{array}{l}\text { Terbanding } \\
\quad(T e b)\end{array}$} & \multirow[t]{2}{*}{$\begin{array}{l}\text { Pembanding } \\
\text { (Pem) }\end{array}$} \\
\hline & & Ter & Pem & & & \\
\hline 1 & $\begin{array}{l}\text { Kalau matahari } \\
\text { hendak masuk } \\
\text { ke } \\
\text { perhentiannya, } \\
\text { ia akan } \\
\text { memancarkan } \\
\text { sinar yang } \\
\text { seperti emas } \\
\text { disepuh ke } \\
\text { puncak gunung } \\
\text { (hlm.48) }\end{array}$ & Verba & Verba & Seperti & $\begin{array}{l}\text { Kalau } \\
\text { matahari } \\
\text { hendak masuk } \\
\text { ke } \\
\text { perhentiannya, } \\
\text { ia akan } \\
\text { memancarkan } \\
\text { sinar }\end{array}$ & $\begin{array}{l}\text { Emas } \\
\text { disepuh ke } \\
\text { puncak } \\
\text { gunung }\end{array}$ \\
\hline 2 & $\begin{array}{l}\text { Air matanya } \\
\text { bercucuran, } \\
\text { laksana mutiara } \\
\text { yang gugur dari } \\
\text { karangnya. } \\
\text { (hlm.77) }\end{array}$ & Verba & Verba & Laksana & $\begin{array}{l}\text { Air matanya } \\
\text { bercucuran }\end{array}$ & $\begin{array}{l}\text { Mutiara yang } \\
\text { gugur dari } \\
\text { karangnya }\end{array}$ \\
\hline 3 & $\begin{array}{l}\text { Tiadalah } \\
\text { diketahuinya air } \\
\text { matanya jatuh } \\
\text { bertititk-titik } \\
\text { sebagai air } \\
\text { mayang enau } \\
\text { baru dipancung. } \\
\text { (hlm.104) }\end{array}$ & Verba & Verba & Sebagai & $\begin{array}{l}\text { Diketahuinya } \\
\text { air matanya } \\
\text { jatuh bertititk- } \\
\text { titik }\end{array}$ & $\begin{array}{l}\text { Air mayang } \\
\text { enau baru } \\
\text { dipancung }\end{array}$ \\
\hline 4 & Tetapi meskipun & Verba & Verba & Sebagai & ia lambat- & Raja berjalan \\
\hline
\end{tabular}




\begin{tabular}{|c|c|c|c|c|c|c|}
\hline & $\begin{array}{l}\text { ia lambat-lambat } \\
\text { turun ke sebelah } \\
\text { barat sebagai } \\
\text { raja berjalan } \\
\text { lakunya... } \\
\text { (hlm.129) }\end{array}$ & & & & $\begin{array}{l}\text { lambat turun } \\
\text { ke sebelah } \\
\text { barat }\end{array}$ & lakunya \\
\hline 5 & $\begin{array}{l}\text { Karena pohon } \\
\text { tembakau pada } \\
\text { waktu itu telah } \\
\text { tinggi, sehingga } \\
\text { badan mereka } \\
\text { itu kelindungan } \\
\text { hanya kepala } \\
\text { sajalah yang } \\
\text { terulur ke atas } \\
\text { sebagai terapung } \\
\text { di atas laut } \\
\text { rupanya. (hlm. } \\
\text { 129) }\end{array}$ & Verba & Verba & Sebagai & $\begin{array}{l}\text { kepala sajalah } \\
\text { yang terulur } \\
\text { ke atas }\end{array}$ & $\begin{array}{l}\text { terapung di } \\
\text { atas laut } \\
\text { rupanya }\end{array}$ \\
\hline 6 & $\begin{array}{l}\text { Terpancarlah } \\
\text { sinarnya yang } \\
\text { amat permai itu, } \\
\text { keluar dari pada } \\
\text { suatu benda } \\
\text { yang bundar } \\
\text { sebagai anak } \\
\text { panah yang } \\
\text { melayang } \\
\text { daripada } \\
\text { busurnya. } \\
\text { (hlm.132) }\end{array}$ & Verba & Verba & Sebagai & $\begin{array}{l}\text { Terpancarlah } \\
\text { sinarnya }\end{array}$ & $\begin{array}{l}\text { anak panah } \\
\text { yang } \\
\text { melayang } \\
\text { daripada } \\
\text { busurnya }\end{array}$ \\
\hline 7 & $\begin{array}{l}\text { Layar pun } \\
\text { terkembang } \\
\text { semua sebagai } \\
\text { sayap burung } \\
\text { yang sedang } \\
\text { melayang di } \\
\text { udara. (hlm. } \\
\text { 148) } \\
\end{array}$ & Verba & Verba & Sebagai & $\begin{array}{l}\text { Layar pun } \\
\text { terkembang }\end{array}$ & $\begin{array}{l}\text { Sayap burung } \\
\text { yang sedang } \\
\text { melayang di } \\
\text { udara }\end{array}$ \\
\hline \multicolumn{4}{|c|}{ ontoh (9) } & \multicolumn{3}{|c|}{ emas disepuh ke puncak gunung } \\
\hline \multicolumn{4}{|c|}{$\begin{array}{l}\text { Kalau matahari hendak masuk ke } \\
\text { perhentiannya, ia akan memancarkan } \\
\text { sinar yang seperti emas disepuh ke } \\
\text { puncakgunung. (hlm.48) }\end{array}$} & \multicolumn{3}{|c|}{$\begin{array}{l}\text { merupakan pembanding. Komponen } \\
\text { makna penyama pada kedua contoh } \\
\text { kalimat tersebut adalah cahaya yang } \\
\text { dipancarkan; } \quad \text { tampilan warna. }\end{array}$} \\
\hline $\begin{array}{l}\text { } \\
\text { peml } \\
\text { pada } \\
\text { mato } \\
\text { perhe } \\
\text { sinar }\end{array}$ & $\begin{array}{l}\text { gan wilayah } \\
\text { inding yang } \\
\text { contoh (9) yait } \\
\text { ari hendak } \\
\text { tiannya, ia aka } \\
\text { lerupakanterbano }\end{array}$ & $\begin{array}{l}\text { bandin } \\
\text { erumpa } \\
\text { kalimat } \\
\text { masuk } \\
\text { meman } \\
\text { g dan }\end{array}$ & $\begin{array}{r}\text { dan } \\
\text { lakan } \\
\text { kalau } \\
\text { ke } \\
\text { arkan } \\
\text { limat }\end{array}$ & $\begin{array}{l}\text { pada ka } \\
\text { masuk } \\
\text { memanc } \\
\text { yang dih } \\
\text { terbenar } \\
\text { disepuh }\end{array}$ & $\begin{array}{l}\text { at kalau ma } \\
\text { perhentiann } \\
\text { an sinarberr } \\
\text { kan oleh mato } \\
\text { ementara itu } \\
\text { puncak guns }\end{array}$ & $\begin{array}{l}\text { hari hendak } \\
\text { ia akan } \\
\text { kna warna } \\
\text { ari saat akan } \\
\text { xalimat emas } \\
g \text { bermakna }\end{array}$ \\
\hline
\end{tabular}


emas yang dicampur dengan sendawa, tawas untuk menuakan warna emas.Jadi, matahari hendak masuk ke perhentiannya, ia akan memancarkan sinar diasosiasikan dengan emas disepuh ke puncak gunung karena mempunyai komponen makna penyama. Penanda simile antara pembanding dan terbanding pada contoh di atas adalah kata sebagai.

Contoh (10)

Air matanya bercucuran, laksana mutiara yang gugur dari karangnya. (hlm.77)

Bagan wilayah terbanding dan pembanding yang diperumpamakan pada contoh (10) adalah pembanding kalimat air matanya bercucuran dengan terbanding kalimat mutiara yang gugur dari karangnya. Komponen makna penyama pada kedua contoh kalimat tersebut adalah sesuatu yang mengalir turun terus-menerus. Sementara, komponen makna pembeda, pada kalimat air matanya bercucuran bermakna air mata yang berpancaran turun dari mata; menangis. Sementara itu, kalimat mutiara yang gugur dari karangnya bermakna mutiara yang jatuh secara bersama-sama dari karangnya. Penanda simile antara pembanding dan terbanding pada contoh di atas adalah kata laksana.Contoh (11)
Tiadalah diketahuinya air matanya jatuh bertititk-titik sebagai air mayang enau baru dipancung. (hlm.104)

Bagan wilayah pembanding dan terbanding yang diperumpamakan pada contoh (11) adalah pembanding kalimat air matanya jatuh bertititk-titik dengan terbanding kalimat air mayang enau baru dipancung. Komponen makna penyama pada kedua contoh kalimat tersebut adalah suatu cairan yang menetes berkali-kali. Sementara itu, komponen makna pembeda, pada kalimat air matanya jatuh bertitiktitikbermakna air mata yang jatuh menetes dari mata. Kalimat air mayang enau baru dipancung bermakna air mayang enau yang jatuh menetes-netes saat dipancung. Penanda simile antara pembanding dan terbanding pada contoh di atas adalah kata sebagai.

\section{e) Perwujudan Simile dalam Kelas Kata Verba dengan Nomina}

Perwujudan simile meliputi terbanding dan pembanding.Adapun terbanding berwujud verba dan nomina. Begitupula dengan pembanding berwujud nomina dan verba. Perwujudan simile dalam kelas kata verba dengan nomina pada novel $A z a b$ dan Sengsara adalah sebagai berikut.

Tabel 5

Perwujudan Simile oleh Merari Siregar dalam Kelas Kata Verba dengan Nomina

\begin{tabular}{|c|c|c|c|c|c|c|}
\hline \multirow[t]{2}{*}{ No } & \multirow{2}{*}{$\begin{array}{c}\text { Kutipan Teks Novel Azab } \\
\text { dan Sengsara }\end{array}$} & \multicolumn{2}{|c|}{ Perwujudan Nomina } & \multirow{2}{*}{$\begin{array}{c}\text { Penanda } \\
\text { Terbanding dan } \\
\text { Pembanding }\end{array}$} & \multirow{2}{*}{$\begin{array}{c}\text { Terbanding } \\
\text { (Teb) }\end{array}$} & \multirow{2}{*}{$\begin{array}{c}\text { Pembanding } \\
\text { (Pem) }\end{array}$} \\
\hline & & Ter & Pem & & & \\
\hline 1 & $\begin{array}{c}\text { Bunga-bunga yang } \\
\text { berkembangan di pantai } \\
\text { laut tawar, serta cahaya } \\
\text { embun yang } \\
\text { berhamburan pada daun } \\
\text { rumput-rumput adalah } \\
\text { pada mata kita sebagai } \\
\text { halaman yang permsai } \\
\text { penuh dengan intan } \\
\text { permata (hlm.148) }\end{array}$ & Verba & Nomina & Sebagai & $\begin{array}{l}\text { Bunga-bunga yang } \\
\text { berkembangan di } \\
\text { pantailaut tawar, } \\
\text { serta cahaya embun } \\
\text { yang berhamburan } \\
\text { pada daun rumput- } \\
\text { rumput }\end{array}$ & $\begin{array}{c}\text { halaman yang } \\
\text { permai penuh } \\
\text { dengan intan } \\
\text { permata }\end{array}$ \\
\hline
\end{tabular}


Contoh (12)

Bunga-bunga yang berkembangan di pantai laut tawar, serta cahaya embun yang berhamburan pada daun rumput-rumput adalah pada mata kita sebagai halaman yang permai penuh dengan intan permata (hlm.148)

Bagan wilayah pembanding dan terbanding yang diperumpamakan pada contoh (12) adalah pembanding kalimat bunga-bunga yang berkembangan di pantai laut tawar, serta cahaya embun yang berhamburan pada daun rumputrumput dengan terbanding kalimat halaman yang permai penuh dengan intan permata. Komponen makna penyama pada kedua contoh kalimat tersebut adalah suatu objek yang indah yang dipenuhi kilauan warna dan cahaya.Sementara itu, komponen makna pembeda, pada kalimat bunga-bunga yang berkembangan di pantai laut tawar, serta cahaya embun yang berhamburan pada daun rumput-rumput bermakna keindahan bunga-bunga yang tumbuh di pantai laut tawar yang dijatuhi cahaya embun yang menyinari halaman tersebut. Kalimat halaman yang permai penuh dengan intan permatabermakna halaman yang indah yang dipenuhi dengan kilauan intan permata.Jadi, bunga-bunga yang berkembangan di pantai laut tawar, serta cahaya embun yang berhamburan pada daun rumputrumputdiasosiasikandengan halaman yang permai penuh dengan intan permata karena memiliki komponen makna penyama.Penanda simile antara pembanding dan terbanding pada contoh di atas adalah kata sebagai.

\section{Simpulan}

Berdasarkan hasil penelitian dalam pembahasan sebelumnya dapat disimpulkan beberapa hal yang menjadi temuan dalam penelitian ini terkait perwujudan simile oleh Merari Siregar dalam novel Azab dan Sengsara.

Terdapat lima perwujudan simile oleh Merari Siregar dalam novel Azab dan Sengsara, yakni (1) perwujudan simile dalam kelas kata nomina dengan nomina; (2) perwujudan simile dalam kelas kata nomina dengan adjektiva; (3) perwujudan simile dalam kelas kata adjektiva dengan verba; (4) perwujudan simile dalam kelas kata verba dengan verba; (5) perwujudan simile dalam kelas kata verba dengan nomina. Sementara, penanda simile yang digunakan oleh Merari Siregar dalam novel Azab dan Sengsara adalah sebagai, ibarat, seperti, tak ubahnya, laksana, dan seolah-olah.

\section{Daftar Acuan}

Ahmadi, M. 1990. Dasar-dasar Komposisi Bahasa Indonesia. Malang: Yayasan Asah Asih Asuh.

Endraswara, Suwardi. 2003. Metodologi Penelitian Sastra (Epistemologi, Model, Teori, dan Aplikasi). Yogyakarta: PN. Pustaka Widyatama.

Fananie, Zainuddin. 2000. Telaah Sastra. Surakarta: Muhammadiyah University Press.

Iye, Risman and Susiati. 2018. "Nilai Edukatif dalam Novel Sebait Cinta di Bawah Langit Kairo Karya Mahmud Jau hari Ali (Educative Values in Sebait Cinta di Bawah Langit Kairoby Mahmud Jauhari Ali). Sirok Bastra, 6 (2), 185-191.

Jabrohim. 2000. Metodologi Penelitian Sastra. Yogyakarta: Hanindita Graha Widya. 
Junus, Umar. 1989. Stilistika: Suatu Pengantar. Kuala Lumpur: Dewan Bahasa dan Pustaka Kementerian Pendidikan Malaysia.

Keraf, Gorys. 2010. Diksi dan Gaya Bahasa. Jakarta: PT Gramedia Pustaka Utama.

Kridalaksana, Harimurti. 2009. Kelas Kata Dalam Bahasa Indonesia. Jakarta: PT Gramedia Pustaka Utama.

. 2011. Kamus Linguistik. Edisi Ketiga. Jakarta: PT Gramedia Pustaka Utama.

Mahsun. 2013. Metode Penelitian Bahasa (Tahapan Strategi, Metode dan Tekniknya). Jakarta: PT Raja Grafindo Persada.

Moleong, Lexi. 2007. Metodologi Penelitian Kualitatif. Bandung: Remaja Rosdakarya.

Munir, Saiful, Nas Haryati S., dan Mulyono. 2013. "Diksi dan Majas dalam Kumpulan Puisi Nyanyiandalam Kelam Karya Sutikno W. S: Kajian Stilistika". JurnalSastra Indonesia. Vol. 2, No. 1.

Nurgiyantoro, Burhan. 2002. Teori Pengkajian Fiksi. Yogyakarta: Gadjah Mada University Press.
2014. Stilistik. Yogyakarta: Gadjah Mada University Press.

Rachman, Abdul, Chairil Effendy, dan Totok Priyadi. 2013. "Majas Metafora pada Kumpulan Sajak Chairil Anwar Aku Ini Binatang Jalang". Jurnal Pendidikan dan Pembelajaran.Vol2, No. 6.

Ratna, Nyoman Kutha. 2016. Stilistika Kajian Puitika Bahasa, Sastra, dan Budaya. Yogyakarta: Pustaka Pelajar.

Semi, M. Atar. 1989. Kritik Sastra. Bandung: Angkasa.

Siregar, Merari. 1993. Azab dan Sengsara. Jakarta: Balai Pustaka.

Sudjiman, Panuti. 1993. Bunga Rampai Stilistika. Jakarta: Pus taka Utama.

Susiati, Susiati, and Risman Iye. 2018. "Kajian Geografi Bahasa dan Dialek di Sulawesi Tenggara: Analisis Dialektometri". Gramatika. Vol. 6. No. 2.137-151.

Susiati. 2017. "Majas Dalam Novel Azab dan Sengsara Karya MerariSiregar". Jurnal Welia. Vol. 2. No. 2.

Tarigan, Henry Guntur. 1986. Pengajaran Semantik. Bandung: Angkasa. 
Kelasa, Vol. 14, No. 2, Desember 2019: 205-222 